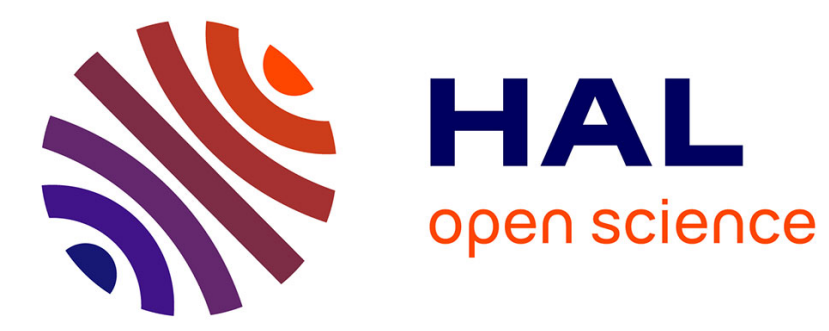

\title{
Children in residential care and school engagement or school 'dropout': what makes the difference in terms of policies and practices in England and France?
}

Benjamin Denecheau

\section{- To cite this version:}

Benjamin Denecheau. Children in residential care and school engagement or school 'dropout': what makes the difference in terms of policies and practices in England and France?. Emotional and Behavioural Difficulties, 2011, 16 (3), pp.277-287. 10.1080/13632752.2011.595093 . hal-01224600

\author{
HAL Id: hal-01224600 \\ https://hal.science/hal-01224600
}

Submitted on 18 Nov 2015

HAL is a multi-disciplinary open access archive for the deposit and dissemination of scientific research documents, whether they are published or not. The documents may come from teaching and research institutions in France or abroad, or from public or private research centers.
L'archive ouverte pluridisciplinaire HAL, est destinée au dépôt et à la diffusion de documents scientifiques de niveau recherche, publiés ou non, émanant des établissements d'enseignement et de recherche français ou étrangers, des laboratoires publics ou privés. 


\section{Children in Residential Care and school engagement or school 'dropout': what makes the difference in term of policies and practices in England and France?}

\section{Benjamin Denecheau}

Benjamin.denecheau@ijvs.org

University of Bordeaux, France ; University of Portsmouth, England; International Observatory of Violence and School

Edited version: http://www.tandfonline.com/toc/rebd20/16/3

\section{ABSTRACT}

In both England and France, looked after children are more likely to have problems in school, relatively low levels of academic achievement and drop out early from education, in comparison with other children. Children in residential care in both countries tend to represent those in most difficulty. This paper is based on a comparative study into the education of children in residential care in France and in England, with a specific focus on identifying positive responses and initiatives. The research seeks to compare and transfer ideas about how to address the issue of educational engagement and school 'dropout' in children's residential care. The study is conducted within a consideration of both national care systems and public policies. One of the objectives is to identify protective factors and good practice with respect to the promotion of school engagement and positive achievement within the residential care systems for children in England and France. The proposed paper will present the first results and analysis of this research. The research compares how both countries respond nationally and locally to the needs of these children. The research took place in two French departments (départements) in 2008-2009 and in two English county local authorities in 2009-2010. The research includes observations and secondary data analysis, as well as interviews with children and professionals. 


\section{THE RESEARCH}

The research is a comparative study between France and England. The aim is to study the education of Looked After Children (LAC) in France and England, and in particular to consider good practices, policies and experiences that have a positive impact and could help improve children's education and achievement. In England, there is research over a 20 years of academic literature whereas in France this topic is just starting to gain salience.

\section{BACKGROUND}

\section{English literature}

Since Essen's publication in 1976, research regularly points to the poor achievement of looked after children in comparison with the rest of the population (Berridge, Dance, \& Beecham, 2008; Biehal, Clayden, \& Stein, 1992; Essen, Lambert, \& Head, 1976; Heath, Colton, \& Aldgate, 1994; Jackson, 2006; Jackson \& McParlin, 1987; Martin \& Jackson, 2002).Children in care are also more likely to be excluded from school, have more issues of attendance, leave school earlier and have a higher rate of unemployment than the general population (Bevort \& Trancart, 2003; Goddard, 2000; Harker, DobelOber, Lawrence, Berridge, \& Sinclair, 2003). These disadvantages affect their education, and life opportunities, physical, mental and social well-being (Chase, Simon, \& Jackson, 2006). They suffer structural marginalisation, due to the lack of efficient responses from social services and are more likely to have mental health disorders (McAuley \& Davis, 2009; McParlin, 1996). In 1983, Sonia Jackson analysed this population and started to discuss what causes could be associated with these educational difficulties in an article which is often cited as the benchmark on this topic (Jackson \& McParlin, 1987). Since this study, the contributory factors of LAC's low achievement are now better understood thanks to a wide corpus of research. Some of the more influential elements occur before any placement. Children in care have mainly experienced traumatic backgrounds, neglect or maltreatment, which could have a deep impact on their concentration and well-being. LAC mainly come from socially deprived families and environments (Bebbington \& Miles, 1989; ODAS, 2003). These families tend to have shorter schooling and achieve less than the global population, and this weakens children's education (Janosz, LeBlanc, Boulerice, \& Tremblay, 1997; Kronick \& Hargis, 1998; Rumberger, 1987). Children in care are more likely come from families where there are mental health disorders, alcohol problems and conduct disorders (DoH, 1995).

Some of the particular features of care provision can also have a negative influence on education. The instability of the placement or the school placements are frequently reported and they have a direct impact on children's education and achievement (Fletcher-Campbell \& Archer, 2003; Millet \& Thin, 2005). Care workers have an important influence on LAC. The lack of professional efficiency forms one of the main elements cited by the literature as having a negative effect. Inadequate corporate parenting, in particular the failure of social services and education departments to work together adequately, usually due to a lack of communication and coordination malfunctioning make education more difficult (Berridge, et al., 2008; Harker, et al., 2003). Professionals are also influential in the way they elaborate the objectives of the care: the low expectations of care workers and social workers have for these children can hamper positive progression (Borland, 2000; Firth \& Horrocks, 1996). Professionals sometime do not value and prioritise education (Harker, et al., 2003). A lack of educational materials and facilities is also a a major factor impeding children's progress when they need to complete home work or study at home. (Martin \& Jackson, 2002). Individual factors, such as low self-esteem or a lack of confidence can also interfere with education (Jackson \& McParlin, 1987). 
At school, LAC tend to have more exclusions.(Jackson, 1994), this is a high risk factor associated with school drop out (Fortin, Marcotte, Royer, \& Potvin, 2005a).

Later research adopts a positive perspective to these issues (Jackson, 1998; Lindsay \& Foley, 1999; Little \& Kelly, 1995; Martin \& Jackson, 2002; Weick \& Saleebey, 1995). Some protective factors have been identified that reinforce educational achievement namely: reducing the stockpile of children's problems, reinforcing encouragement and educational support, ensuring the stability and security of placements, guaranteeing a secure base, reinforcing self-esteem/self worth selfdirectedness and self efficacy of children and young people, having a mentor or a privileged relationship with a supportive adult, having a quiet place to work and efficient partnership between services (Gilligan, 2001). It is important to develop the skills of professionals to enable them to work together and to increase this form of partnerships (Parker, Ward, Jackson, Aldgate, \& Wedge, 1991). The responsibility of the education of Looked After Children is not one person's responsibility, but that of professionals, locally and nationally (Gallagher, Brannan, Jones, \& Westwood, 2004) in the development of corporate parenting. Corporate parenting is describe as "the collective responsibility of local authorities to achieve good parenting” (DfEE/DoH, 1999, p. 12).

\section{French Literature}

A literature search failed to find any French research on the subject. There is some research on Children in Care, and few books written by professionals or former professionals refer to it, but only superficially and none has a whole chapter dedicated to it. The only French research available is on adults who have left a placement (Dumaret \& Coppel-Batsch, 1996; Frechon \& Dumaret, 2008). As Sonia Jackson reported in 1987 in England, the lack of research on this topic show that, in France, it is not a subject of interest to researchers. According to French teachers, Looked After Children are not seen as a distinct population, and according to French care workers, their education does not warrant a specific approach.

\section{The school dropout risk/protective factors approach}

The literature on school dropouts provides useful strands of material relating to LAC (Fortin, Marcotte, Royer, \& Potvin, 2005b; Janosz, et al., 1997). If school dropout is defined as leaving school without qualifications, literature describing the complex and long process which precede this leaving is of importance. Most of the time it is during this period that elements interfere with education and could lead to leaving without diploma or qualification (Millet \& Thin, 2005).

The majority of the elements pointed out by the English research on education of LAC, and the elements from this research in both countries indicate that being a LAC is a risk factor in dropping out of schooling. For example, research has identified as risk factors the socio-economic factors (BattinPearson, et al., 2000; Jimerson, Egeland, Sroufe, \& Carlson, 2000; Rumberger, 1987), the frequent moves, the familial climate (Potvin, et al., 1999) and its structure (Rumberger, 1987), the low support, the low expectations, the weak supervision from parents or their social activities, or the lack of material and learning opportunities (Alexander, Entwisle, \& Horsey, 1997; Fortin, et al., 2005b). These elements are frequent in Looked After Children's lives. Moreover, some indicators of a high risk of school breakdown are more frequent for children in care, like truancy (Rumberger, 1987), or behaviours difficulties (Jimerson, et al., 2000).

The accumulation of risk factors raises the risk of drop out. Children in care accumulate risk factors, because of the maltreatment or neglect most of them have experienced, and their resultant low selfesteem or depression. They usually come from a family with poor economic circumstances and a low levels of parental support. The placement resolves some issues, but can be a cause of further factors, like low expectations, low support and frequency of moves between placements. 


\section{MeTHODOLOGY}

The main part of the research was composed of semi-structured face-to-face interviews with children, young people, social workers, care workers and managers $(n=90)$. They are complemented by secondary data analysis and observation. National data and data from the local authority (or the French area) was analysed as were the children's case files. More than five hundred hours were spent in the homes in France and in England in order to have a better understanding of them and the way they were working.

The sample is composed of four long term children homes in each country. one area in France and one local authority in England form the geographic boundaries of the study. The home managers were asked to agree to be part of the research. There were some refusals in France, none in England. As indicated earlier homes were visited and a lot of people in the home were interviewed. Consent from each child in the study was sought The young in the homes are six to twenty years old. Children aged 14 or more formed a larger part of the sample as, they have a clearer view of their situation and in some situations(mainly in France)., they have to start thinking about what they want to do in the future In England twenty care workers, one teacher, five social workers, one psychologist, four managers and ten young people (five boys and five girls) were interviewed. In France twenty one care workers, three teachers, three managers, four psychologists and thirty-one young people (thirteen boys and eighteen girls) were interviewed.

The data was anonymised, the interviews are treated as confidential and the recordings were held securely and anonymously. All staff and children were provided with information about the research and their participation was voluntary. Mindful of the vulnerability of the young people and every effort to avoid any line of questioning that could have been upsetting was made.

\section{CONTEXT}

Both systems have the protection and the safety of the child as a first objective, and they are quite similar in the construction of their response to the protection of children and young people. The main placements of LAC are in foster care and residential homes. Children and young people are also placed in the family, the extend family or with friends. In both countries residential care hosts the most challenging children (Sellick, 1998). In England, these children achieve less and have higher rates of exclusion and truancy than children in foster care (Goddard, 2000). The biggest difference between the two systems is that the English care system has integrated education and achievement of young people as main objectives and has developed some specific support to try to reach these aims.

\section{Discussion}

An analysis of national data reveals a gap between the two countries. In England, data are collected on this population notably from educational sources. The continuous publication of data on this population shows that there are still some challenges to be met. The literature shows an achievement gap between children in care and the general population. Children in care still achieve less than the general population on average, only $14 \%$ of looked after children achieved five or more GCSE/GNVQ $\mathrm{A}^{*} \mathrm{C}$, compared with $65 \%$ of the whole school population in $2008,28 \%$ of looked after children have a special educational needs statement, compared with only $3 \%$ of the whole school population (DCSF, 2009b).

In France, these data are not collected, either nationally or locally. The sample for this research is not big enough to have significant information about achievement and qualifications. The low number does not permit any generalizations. Insufficient data is available to know how far the population of 
the sample is representative of the children in care in France, but in general, from the interviews, an insight into the situation of children in care was gained, particularly from the staff point of view. As with interviews in England, those spoken to in France highlighted the degree of educational difficulties Looked After Children have.

\section{Truancy, attendance and expulsion}

The gathering of data is also conducted differently. In England, staff have a register of attendance, they note if a child or young person is at school, refuses to go, is sick, is missing, has an authorized absence, is sent home, is in police custody or in court, is attending a meeting, or if he has no educational placement or no provision for the day. French homes do not have such a register. There is some correspondence between schools and care workers and monitoring of school reports and educational reports, but it is less common practice.

The comparison of some data allows initial analysis about the differences between the two countries and the young people who are in residential care. In three English homes from the sample, the overall truancy rate over three years is around $25 \%$, and the exclusions rate is around $5 \%$. These are strong risk factors of school dropout and these two rates are quite high in comparison with the global population (DCSF, 2009c, 2009d).

The French data are, again, not significant but they are a first indicator showing the need to go further. Analysis shows that, for 102 school pupil years (over 3 years) 21 exclusions and 59 days of truancy were recorded. The specification of each day (sickness, day off, custody, no provision...) is not specified and the first date and the last date of each placement are not always referenced. So it is impossible to have an exact rate of exclusion and truancy. This tendency is confirmed by the interviews and shows that truancy and exclusion are much less present in France. Without a quantitative analysis, it seems that English young people have a greater absence rate, while in France the norm of going to school every day is stronger.

\section{The state of education of Looked After Children in France}

In France, the limited literature reveals similarities in the research and policies with those in England twenty years ago. Children in care usually came from a family with social difficulties (ODAS, 2003), they are in care for the same reason as in England, mainly because of physical and mental maltreatment. The educational issues of this population are quite similar with the one observed in England. The majority of the professionals report big issues in the education, achievement and orientation of young people. This shows the need for quantitative data and analysis. Children in care from this research are more likely to go to vocational training or placement in a special school than occurs in the general population. The specific issues emerging from this research, in contrast to the situation in England, are the number of staff, the number of children and the environment of work. The French staff/ratio is 1 staff for 4 to 6 young people (it's 1 for 1 to 2 in England). The homes are quite a lot bigger than in England and some could have up to 28 places (6 in England). So there is less staff to look after the children. The biggest consequence is that staff don't have a lot of time to dedicate to every child or young person, and very little time to manage education. Children and young people do not have a quiet study room to do their work, and usually they do it in a common room, or in their bedroom. These conditions can be a discouragement to working in the home.

\section{The evolution of the care home population}

The care home population of England has evolved over time to include more children from the most difficult backgrounds. The care system has tried to reduce the number of children in care (Rowlands \& Statham, 2009) and to reduce the proportion of children in residential care (DCSF, 2009a). The children and young people in residential care are those who have experienced a lot of placement breakdown or where social workers and care workers consider that a foster care placement is not appropriate for them. Social services tend to value foster care over placement in children's homes. The 
latter is usually a step after foster care: children who are placed in a home have ordinarily been in several foster care placements. There is a slow shift in the constitution of the population in residential care towards the most challenging children and young people, with the most complicated situations. These changes seem to have an impact on care workers, in terms of their motivation and impression about what is possible and what could they expect from children in homes. In France the distribution in the different type of placement remains static (Bailleau \& Trespeux, 2009). Some young people are placed in residential care as their first placement. Thus the two populations are different both in terms of issues and challenges.

\section{The level of professional expectations}

In England, despite the findings of research and support available, some negative or pessimistic expectations from Care Workers can still be observed. The data from this study tentatively provides some explanations. Firstly, the progression of the population of children and young people in residential care could have an impact on the carers' points of view. The care workers don't see this progression and they tend to maintain the impression of a population accumulating difficulties and facing a difficult future. Resignation to this situation was witnessed frequently in the interviews. Children's and young people's capacity and possibilities are perceived as low, and the care worker's consequent expectations are at the same low level. However, the English government, and local authorities encourage professionals to have high expectations in recent times (DfES, 2006; SEU, 2003).

In France, the situation is quite similar to that in England twenty years ago, education of children in care is not an objective for social workers and care workers. They don't work in support of it they perceive this to be solely responsibility of teachers, while they focus on children's trauma and immediate well-being, this can have serious consequences on the children's future. Care workers from both countries reported a lack in their training with regard to their role in children's education. In France the matter of education is not approached and the professional interviewed are convinced that this is really important to work efficiently with children. So, there is a main feeling that education should be valued. In England they have a specific one day training for this topic, but it is still not sufficient according to care workers, they need more training and more tools to work with in supporting children and young people's education.

\section{Work in partnership}

English professionals (social worker and care workers) pointed out some real progress in their partnerships with other services. Some initiatives have been implemented which improve partnership and cooperation between department or services, like the Personal Education Plan (PEP) (DfEE/DoH, 2000, Hayden, 2005). Some specific posts in schools, local authorities and children home have been implemented so that at least one professional is aware of the children's educational progression. These staff are aware of the work and the tasks of each other, and this facilitates cooperative practice. In the children's home there is an educational lead, in the school there is on designated teacher, and in the social services, there are some education welfare officer and the manager for vulnerable children. In schools, the awareness of the particularities of this population is supported by the designated teacher. They know the LAC who are in the school and they are aware of their education. In the children services of the local authorities, the education welfare officer is in charge of the school attendance and he meets the parents or the carers if a problem arises. Another post was created: the manager for vulnerable children. Their objective is to work specifically with children and they coordinate meetings between education services and carers to improve the work on education. Children homes give the responsibility of education to one person, the educational lead. He has to create a dynamic of the education team (set up a time table and a school day in the home, support children school work, etc.) 
In France care workers do not see teachers very often, they mainly meet each other when a problem arises, and it can be in an ambiance of conflicts or tensions. There are some disagreements about sharing of information. There is no link between different services, each places responsibility onto the other: care workers are not teachers and cannot work on education and teachers can not deal with the specific problems the children encounter

\section{The impact of the care home climate}

Placement in a care home provide an environment where the child or the young person has a new opportunity to develop. If he or she is in long term care this new home can have as major influence as would a family. The extent of this impact depends on the time he or she is in this home and the contact the child has with family. In both countries, children homes can be quite different in their dynamic and their climate. Different elements interact and influence each other and can have a big impact on professionals' working and the way children and young people are looked after. Different actors have their own influence on this climate. First of all the manager of the home is mainly cited in interviews as the source of this dynamic. The way he/she manages the home and the care home team provides the direction and extent to which education is valued or not. In each home with education as a main objective, the education lead seemed to be dynamic and influential on the team. They are not only the main link with schools, but also develop a real priority for education, with routines for working at the home, linking with schools and key teachers, they know the school system, job or vocational options..

The personalities of children in a home at any particular time also has an important impact on the home dynamic. Children influence can each other in positive ways but also often negatively. Children also have a big influence on the staff dynamic and their overall view. For example, a group who accumulate difficulties can reduce care workers motivation and affect a shift on their standards, they could see this group as typical of the Looked After Children population, and lowering their perception about what they think is possible can cause a reduction in care workers' objectives.

\section{The variation in type and the level of support}

As discussed, some changes have been made in England for the support of Looked After Children, especially regarding their education. During the interviews, the improvement in the level of support was recognized by professionals. They recognized that the adaptation of the environments in children's homes (less children in the home, room for school work), the designation of specific staff with responsibility for education and the optimization of the partnership between the services are seen as very supportive of the children. Staff feel that is helpful for them and for children and young people, even though some progress is still needed. In France support remain the same as in the past focussed on care. In homes, there is little support for education because of the low expectations of care workers, they can't spare a lot of time for each child, particularly for homework. Staff are few in number given the number of children, they have a heavy work load, and this could be a reason for insufficient time being devoted to each individual child. Those children and young people who are well engaged indicated that this individual attention was a important source of support. They usually cited one specific care worker (very often their key worker), the education lead, one member or their family, or a peer (friend or their boy/girlfriend) as the person providing this support.

In France young people are going more frequently and earlier into vocational training. They can start as early as year nine (about fourteen years old). This seems to engage better those who have difficulties in mainstream school, and serves to keep them in schooling with objectives and ambition.

In France, there is no specific training geared towards the support of the education of Looked After Children, neither for teachers nor care workers. However some local initiatives are organised by some homes and an initiatives are sometimes launched by individual managers. Some of these solutions are quite similar to the institutional support put in place in England. 
Cross-professional experience can be very important. Some of the care workers who value education come mostly from the education/schooling system, some of them are former-teachers, and they are among the most dynamic regarding school issues. They insist on the importance of regularity in the school work and keeping a routine for children and young people. Usually, education is not a priority for care workers, the majority of them insist on the background of children and young people and the reasons that could explain these difficulties, and this can sometimes be used as an excuse to slow down education. The educational staff interviewed in this research insisted on the importance of the initiative in motivating young people and care workers too.

\section{Local initiatives}

With a common base of supports and practices, local initiatives seem to make the differences between the homes. In France, one home from the sample had implemented a lead education staff and a family staff (who is in charge of contact with parents). Care workers interviewed pointed out some positive effects of these developments. They have more time to look after the children and young people, the lead education staff has better contact with the educational network. He has a better knowledge about what is important at school and about what is needed for the child. This role is still strongly attached to the person, not the job. When a lead educationalist moved, the initiative was vulnerable.

In France, state schools don't make specific provisions for pupils with special educational needs. Despite some specific systems for children with specific needs, there is none for those who are in care, and it is perceived as a lack that needs addressing. Care workers work sometimes with private schools, who provide for this. They develop a partnership where specific provisions could be implemented and reviews conducted when necessary. Private schools can be more flexible with pupils, with less children in each group, so they are able to develop more one to one teaching. Some local partnerships could be set up between care home and schools (private and public),but this depends greatly on the individuals. Care workers could work more frequently with some schools because they know some of the teachers, and they know the way they work and believe it is appropriate for the child.

\section{CONCLUSION}

In England, the continuity of gathering data and ongoing research enables one to observe a positive long term evolution of policy, provision and practice (Chase, et al., 2006; Goddard, 2000). Care worker training is maybe the next step to improve engagement with education. In France the value of education and the tools to work in support of education has to be taught in the training of care workers. While there is still some progress to be made, in England education is valued and it has an impact on staff, children and young people. In England, success is due to personal and institutional initiatives whereas in France the success observed is due to personal effort on the part of individual care workers. A policy is urgently needed in France to enable better understanding of the needs of, and support required to improve children's education and achievement. In both countries, residential care does not provide a better educational support than that the average student receives, and there is a need for significant improvement (Heath, et al., 1994) so that LAC students can close the gap in achievement with the rest of the population (Jackson, 1998). 


\section{REFERENCES}

Alexander, K., Entwisle, D., \& Horsey, C. (1997). From first grade forward: Early foundations of high school dropout. Sociology of Education, 70(2), 87-107.

Bailleau, G., \& Trespeux, F. (2009). Bénéficiaires de l'aide sociale départementale en 2008: DREES.

Battin-Pearson, S., Newcomb, M., Abbott, R., Hill, K., Catalano, R., \& Hawkins, J. (2000). Predictors of early high school dropout: A test of five theories. Journal of Educational Psychology, 92(3), 568-582.

Bebbington, A., \& Miles, J. (1989). The background of children who enter local authority care. British Journal of Social Work, 19(1), 349.

Berridge, D., Dance, C., \& Beecham, J. (2008). Educating difficult adolescents: effective education for children in public care or with emotional and behavioural difficulties. London: Jessica Kingsley Pub.

Bevort, A., \& Trancart, D. (2003). Les comparaisons internationales dans les recherches et les débats sur les systèmes éducatifs. In M. Lallement \& J. Spurk (Eds.), Stratégies de la comparaison internationale (pp. 121-133). Paris: CNRS Editions.

Biehal, N., Clayden, J., \& Stein, M. (1992). Prepared for living? A survey of young people leaving the care of three local authorities.

Borland, M. (2000). Educating accommodated children. Child Welfare, Policy and Practice, 165183.

Chase, E., Simon, A., \& Jackson, S. (2006). In care and after: a positive perspective: Routledge.

DCSF. (2009a). Children looked after in England year ending 31 March 2009, Statistical first release. London: Department for Children, Schools and Families.

DCSF. (2009b). Outcome indicators 2008, Statistical first release.

DCSF. (2009c). Permanent and fixed period exclusions from schools and exclusion appeals in England, Statistical First Release. London: Department for Children, Schools and Families.

DCSF. (2009d). Pupil absence - spring 2009 term report, Statistical release. London: Department for Children, Schools and Families.

DfEE/DoH. (1999). Draft guidance on the education of children looked after by local authorities. London: Department for Education and Employment/Department of Health.

DfEE/DoH. (2000). Education of young people in public care: guidance. London: Department for Education and Employment/Department of Health.

DfES. (2006). Care matters: transforming the lives of children and young people in care: DfES.

DoH. (1995). Child protection: messages from research. London: The Stationary Office.

Dumaret, A., \& Coppel-Batsch, M. (1996). Evolution à l'âge adulte d'enfants placés en familles d'accueil. La Psychiatrie de L'Enfant, 39(2), 613-671.

Essen, J., Lambert, L., \& Head, J. (1976). School attainment of children who have been in care. Child: care, health and development, 2, 339-351.

Firth, H., \& Horrocks, C. (1996). No home, no school, no future: exclusions and children who are 'looked after'. London: Routledge.

Fletcher-Campbell, F., \& Archer, T. (2003). Achievement at Key Stage 4 of young people in public care: Department for Education and Skills.

Fortin, L., Marcotte, D., Royer, É., \& Potvin, P. (2005a). Facteurs personnels, scolaires et familiaux différenciant les garçons en problèmes de comportement du secondaire qui ont décroché ou non de l'école. Nouveaux cahiers de la recherche en éducation, 8(2), 79-88. 
Fortin, L., Marcotte, D., Royer, É., \& Potvin, P. (2005b). Hétérogénéité des élèves à risque de décrochage scolaire: facteurs personnels, familiaux et scolaires. In DeBlois (Ed.), $L a$ réussite scolaire. Comprendre et mieux intervenir (pp. 51-64). St-Nicolas: PUL.

Frechon, I., \& Dumaret, A. (2008). Bilan critique de 50 ans d'études sur le devenir adulte des enfants placés. Neuropsychiatrie de l'enfance et de l'adolescence, 56(3), 135-147.

Gallagher, B., Brannan, C., Jones, R., \& Westwood, S. (2004). Good practice in the education of children in residential care. British Journal of Social Work, 34(8), 1133-1160.

Gilligan, R. (2001). Promoting resilience A resource guide on working with children in the care system.

Goddard, J. (2000). The education of looked after children. Child and family social work, 5, 79-86.

Harker, R., Dobel-Ober, D., Lawrence, J., Berridge, D., \& Sinclair, R. (2003). Who Takes Care of Education? Looked after children's perceptions of support for educational progress. Child \& Family Social Work, 8(2), 89-100.

Hayden, C. (2005). More than a piece of paper?: Personal education plans and'looked after'children in England. Child \& Family Social Work, 10(4), 343-352.

Heath, A., Colton, M., \& Aldgate, J. (1994). Failure to escape: a longitudinal study of foster children's educational attainment. British Journal of Social Work, 24(3), 241.

Jackson, S. (1994). Educating children in residential and foster care. Oxford Review of Education, 20(3), 267-279.

Jackson, S. (1998). Looking after children: a new approach or just an exercise in formfilling? A response to Knight and Caveney. British Journal of Social Work, 28(1), 45.

Jackson, S. (2006). Looking after children away from home. Past and present. In E. Chase, A. Simon \& S. Jackson (Eds.), In care and after: a positive perspective: Routledge.

Jackson, S., \& McParlin, P. (1987). The education of children in care: School of Applied Social Studies University of Bristol.

Janosz, M., LeBlanc, M., Boulerice, B., \& Tremblay, R. (1997). Disentangling the weight of school dropout predictors: A test on two longitudinal samples. Journal of Youth and Adolescence, 26(6), 733-762.

Jimerson, S., Egeland, B., Sroufe, L. A., \& Carlson, B. (2000). A prospective longitudinal study of high school dropouts examining multiple predictors across development. Journal of School Psychology, 38(6), 525-549.

Kronick, R., \& Hargis, C. (1998). Dropouts: Who Drops Out and Why. And the Recommended Action: Charles C. Thomas, Publisher, Ltd., 2600 South First Street, Springfield, IL 627949265.

Lindsay, M., \& Foley, T. (1999). Getting them back to school-touchstones of good practice in the residential care of young people. Children \& Society, 13(3), 192-202.

Little, M., \& Kelly, S. (1995). A life without problems?: the achievements of a therapeutic community: Arena.

Martin, P., \& Jackson, S. (2002). Educational success for children in public care: advice from a group of high achievers. Child \& Family Social Work, 7(2), 121-130.

McAuley, C., \& Davis, T. (2009). Emotional well-being and mental health of looked after children in England. Child \& Family Social Work, 14, 147-155.

McParlin, P. (1996). Children 'Looked after'(in Care)-Implications for Educational Psychologists. Educational Psychology in Practice, 12(2), 112-117.

Millet, M., \& Thin, D. (2005). Ruptures scolaires: l'école à l'épreuve de la question sociale: Presses univ. de France.

ODAS. (2003). La décentralisation et la protection de l'enfance, quelles réponses pour quels dangers?

Parker, R., Ward, H., Jackson, S., Aldgate, J., \& Wedge, P. (1991). Looking after children: assessing outcomes in child care: the report of an independent working party established by the Department of Health. London: HMSO. 
Potvin, P., Deslandes, R., Beaulieu, P., Marcotte, D., Fortin, L., \& Leclerc, D. (1999). Risque d'abandon scolaire, style parental et participation parentale au suivi scolaire. Canadian Journal of Education/Revue canadienne de l'education, 24(4), 441-453.

Rowlands, J., \& Statham, J. (2009). Numbers of children looked after in England: a historical analysis. Child and family social work, 14, 79-89.

Rumberger, R. (1987). High school dropouts: A review of issues and evidence. Review of Educational Research, 57(2), 101.

Sellick, C. (1998). The use of institutional care for children across Europe. European Journal of Social Work, 1(3), 301-310.

SEU. (2003). A better education for children in care. London: Social Exclusion Unit, Office of the Deputy Prime Minister.

Weick, A., \& Saleebey, D. (1995). Supporting family strengths: Orienting policy and practice toward the 21st century. Families in Society, 76, 141-141. 